LA-7548-MS

Informal Report

Waste Management Programs and Capabilities Within the Los Alamos Scientific Laboratory

$\frac{\pi}{5}$ 
LA.7548.MS

Informai Report

Speciai Distribution

Issued: October 1978

\title{
Waste Management Programs and Capabilities Within the Los Alamos Scientific Laboratory
}

\author{
Compiled and Edited by
}

B. R. Erdal

D. C. Hoffman

Waste Management Coordinator FY.78

w. C. Luth

Waste Management Coordinator FY-79

Waste Management Advisory Group

G. A. Graves

R. J. Jensen

A. Zerwekh

B. $P$ Erdal

L. S. Germain

L. J. Johnson

B. G. Killian

R. B. Walton

J. G. Freiwald

W. F. Miller

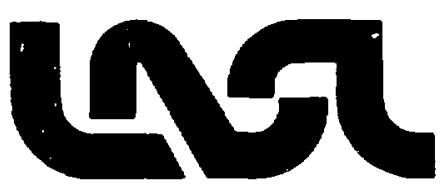


CONTENTS

Abstract . . . . . . . . . . . . . . . . . . . . . . 1

I. Executive Summary . . . . . . . . . . . . . . . . 3

II. Programs by Title and Category . . . . . . . . . . . . 5

Site Selection . . . . . . . . . . . . . . . . . 7

Geologic-Geochemical Environment . . . . . . . . . . 8

Mathematical Modeling . . . . . . . . . . . . . . . . 9

Field Testing and Model Verification . . . . . . . . . 10

Detection and Monttoring . . . . . . . . . . . . . . . . 11

Systems Analysis . . . . . . . . . . . . . . . . . . 12

Waste Handling, Processing, and Recycling Laboratory . . . . 13

III. Programs by Laboratory Division (objectives and funding level) . 15

Applled Photochemistry (AP) . . . . . . . . . . . . 17

Chemistry-Materials Science (CMB) . . . . . . . . . . . 18

Chemistry-Nuclear Chemistry (CNC) . . . . . . . . . . 19

Geosciences (G) .. . . . . . . . . . . . . . . . 22

Health Research $(\mathrm{H})$. . . . . . . . . . . . . 25

Fleld Testing $(J)$. . . . . . . . . . . . . . 27

Energy (Q) . . . . . . . . . . . . . . . . . 29

Systems Analysis and Assessment (S) . . . . . . . . . . 32

Theoretical (T) . . . . . . . . . . . . . . . 33

IV. Divislonal Capabilities . . . . . . . . . . . . . 35

Applied Photochemistry (AP) ............... . 37

Chenistry-Materials Sclence (CMB) ............ 37

Chemistry-Nuclear Chemistry (CNC) . . . . . . . . . 38

Gensctences (G) .................... . 39

Health Research $(H)$................. 40

Fleld Testing (J) . . . . . . . . . . . . . . 41

Energy (Q)......................... 42

Systems Analysis and Assessment (S) . . . . . . . . 43

Theoretical (T). . . . . . . . . . . . . . . 44

V. Divisional Facilities . . . . . . . . . . . . . 45

Applied Photochemistry (AP) ............... 4 4 ?

Chemistry-Materials Science (CMB) . . . . . . . . . 47

Chemistry-Nuclear Chemistry (CNC) ............ 49

Geosciences (G) ................... 51

Health Research $(\mathrm{H})$................. 51

Field Testing $(\mathrm{J})$................. 52

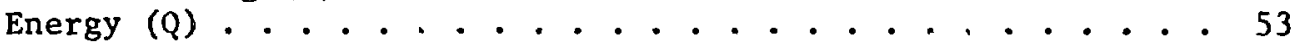

Systems Analysis and Assessment (S) . . . . . . . . . 54

Theoretical $(\mathrm{T})$. . . . . . . . . . . . . 54

VI. LASL Techntcal Organtzation . . . . . . . . . . . . 55 


\section{WASTE MANAGEMENT PROGRAMS AND CAPABILITIES WITHIN}

THE LOS ALAMOS SCIENTIFIC LABORATORY

by

D. C. Hoffman, Waste Management Coordinator FY-78

W. C. Luth, Waste Management Coordinator FY-79

Waste Management Advisory Group
G. A. Graves, ADR
R. J. Jensen, AP
A. Zerwekh, CMB
B. R. Erda1, CNC
L. S. Germain, G
L. J. John 3on, H
B. G. Killian, J
R. B. Walton, Q
J. G. Freiwald, S
W. F, Miler, T

Compiled and edited by B. R. Erdal, CNC-11

\section{ABSTRACT}

This document briefly outlines the varlous programs in radloactive waste management and some related flelds which are currently belng pursued at the Los Alamos Sc1entiflc laboratory. Some additional proposed or known potentlal programs are also outlined, and some of the exlsiting capabllities and facilities of the varlous divisions of the LASL which could be utilized in the solution of waste management problems are also described. Th1s summary is Intended to show the objectives and scope of of our current programs, to ald in the evaluation and coordination of these programs, and to help us identify areas in which we can and should make additional contributfons because of our particular capabilitles and fac1l1t1es. 
EXECUTIVE SUMMARY

In this document we have briefly outlined the various programs in radioactive waste mangement and in some related fields which are currently being pursued at the Los Alamos Scientific Laboratory. Some additional proposed or known potential programs are outlined, and some of the existing capabilities and facilities of the various divisions of the LASL which could be atilized in the solution of waste management problems are also described.

In the first major section or this report, tnese programs are listed only by title within major categories, with some repetition where there are multiple categories of applicability. In the next section, the programs are given by Laboratory division with a short statement for each program giving its objectives or pertinence, and, for each funded waste management program, its FY78 funding level and estimated future trend. (In most instances exact FY79 funding levels are not yet known.) Relevant capabilitles and relevant facilities of the Laboratory divisions involved in these programs are synopsized in the next two sections.

A summary of this type, of course, cannot do Justice to the evolving nature of the research described nor to the full details of the individual programs. More complete or up-to-date information can be obtained, whenever desired, by contacting the Division office associated with the prograin. The LASL technical organization is given in the last section.

This summary is intended to show the objectives and scope of our current programs, to aid in the evaluation and coordination of these frograms, and to nelp us identify areas in which we can and should make additional contributions because of our particular capabilities and facilities. It should also provide a basis for the formulation of new proposals, and for the development of a coherent and worthwhile program of radioactive waste management activities at the Laboretory. We also hope it will be of value to outside agencies in assessing our current programs and our potential for contributing to the solution of problems in this area which is so important to the nation in its utilization of nuclear energy. 
PROGRAMS BY TITLE AND CATEGORY

Site Selectirn

Geologic-Geoshemical Environment

Mathematicat. Modeling

Field Testlig and Model Verification

Detection and Monitoring

Systems Anlysis

Waste Handing, Processing, and Recycling 


\section{SITE SELECTION PROGRAMS}

Program Area

Division

Currently Funded Programs

NTS Terminal Waste Storage Program

CNC, G, J

Evaluation of Transuranium Contaminaced

$\mathrm{H}$

Waste Burial Sites

Radioactive Waste Burial Technology

H

Cohabitation of Weapons Testing and Waste

$J$

Management Activities at the NTS

\section{Related Programs}

Site Selectlou for Nuclear Weapons Tests

Ground Motion Studies

Large Scale Technical Field Programs

$\mathrm{J}$

\section{Potential Programs}

Natural Fission Reactor Investigations

CNC

Pertinent to Site Suitability Criteria

Geologic and Geophysical Characterization

$J$

of a Site; Technical Field Programs 
PROGRAMS IN GEOLOGIC-GEOCHEMICAL ENVIRONMENT

Program Area

Division

Currently Funded Programs

RAD Waste Degradation Studies For WIPP

CMB

Radionuclide Migration Project

CNC

NTS Terminal Waste Storage Program

CNC, G, J

Waste Isolation Safety Assessment Program

$\mathrm{CNC}$

Natural Fission Reactors

CNC

Evaluation of Transuranium Contaminated

$\mathrm{H}$

Waste Burial Sites

Transport of Waste Radionuclides through

Soil

Ecological Behavior of Waste Materials at

H

Los Alamos and Trinity Site

Related Programs

Dissolution of Rocks and Minerals CNC

Heats of Formation of Minerals CNC

GeothermaJ. Circulation Loops and Element CNC

Migration Studies

Permeability and Trace-Element Studies CNC

Potential. Program

Field Measurements for In-Situ

$\mathbf{J}$

Waste Management Experiments 
PROGRAMS IN MATHEMATICAL MODELING

Program Area

Division

Currently Funded Programs

Radionuclide Migration Project

CNC

Evaluation of Transuranium Contaminated

H

Waste Burial Sites

\section{Related Programs}

Porous Flow and Hydrofracture Models J

Distributions of Cracks in Rocks T

Development of the Data Base Characterizing the T

Radionuclide Decay Chains for Waste Materials

Computer Modeling of Fluid Flow through

Porous Media

Potential Programs

Porous Flow, Hydrofracture, and Ground

$J$

Motion Modeling

Computer Modeling of the Transport of

$\mathrm{T}$

Radioactive Waste in Geological Media*

* A proposal exists. 
Program Area

\section{Division}

Currently Funded Programs

Radionuclide Migration Project

CNC

Natural Fission Reactor (OKLO) Program

CNC

Radioactive Waste Burial Technology

H

Cohabitation of Weapons Testing and Waste Management

$\mathbf{J}$

Activities at the NTS

Related Programs

Large Scale Technical Field Programs

J

Safeguards Material Measurement and

$Q$

Accounting - DYMAC

Potential Program

Geologic and Geophysical Characterization

J

of a Site; Technical Field Programs 
Currently Funded Programs

TRU Waste Treatment Demonstration

and Assay Instrumentation Development

Detector Development

\section{Related Programs}

Safeguards Measurement Technology,

International Safeguards \& Training

Surveillance

Nondestructive Assay Technology

for Uranium Resource Evaluation

Monitoring of Nuclear Weapons Tests

\section{Potential Programs}

Advanced Detector and Monitoring Techniques

Field Measurements for In-3itu Waste

J

Management Experiments

Waste Management by Measurement*

Active/Passive Neutron Assay of Fission

Product TRU Waste

Leached Hulls Monitor

Transfer of Safeguards Material

Management Technology for Waste Management

* A proposal exists. 


\section{Related Programs}

Timits/Standards for Radionuclides

H

in Environmental Media

Safequards Material Measurement and

Q

Accounting - DYMAC

Safequards Systems Analysis, Conceptual

Design sind Evaluation of Fuel Cycle Facilities

Q

Statistical Support for Nuclear

$\mathbf{S}$

Accolntability Program

Sensitivity Analysis of Transient

S

Reactor Analysis Code (TRAC)

\section{Potential Program}

Nuclear Fuel Cycle Options Model 
PROGRAMS TN WASTE HANDLING, PROCESSING, AND RECYCLING

Program Area

Division

Currently Funded Programs

238

$\mathrm{PuO}_{2}$ Safety and Environmental Support

CMB

Release Rates of Reactor Products from Stored

CNC

Fuel Elements, Synthetic Uraninite, and Natural

Reactor Ore

$\mathrm{UO}_{2}$ and $\mathrm{ThO}_{2}$ Skull Melting

CNC

Filter Test Methods for Air Cleaning

$\mathrm{H}$

TRU Waste Treatment Demonstration and

H

Assay Instrumentation Development

Waste Management Requirements for

$\mathrm{H}$

Alternative Fuel Cycles

Stabilization of Uranium Mill Tailings

$\mathrm{H}$

Related Programs

Chemistry of Oxo-Complexes of the Light

CNC

Actinides, Theory and Experiment

Ceramic Heat Pipe

Q

Potential Programs

Laser Spectroscopy

AP

Advanced Chemical Processing

AP

Silicate and Titanate Analogues of

G

Natural Minerals as Waste Forms

Incinerator off-Gas Treatment Program*

$\mathrm{H}$

Exhumed Waste Processing Studles to

$\mathrm{H}$

* A proposal exists. 
PROGRAMS BY LABORATORY DIVISION

Objectives

Current and expected funding levels

$\because$ 
APPLIED PHOTOCHEMISTRY (AP) DIVISION

Program Area

1. Laser Spectroscopy

2. Advanced Chemical Processing
Principal object ve

\section{Potential Programs}

Determine absorption frequencies

and cross-sections; necessary

chemical prowessing.

Utilization of laser photochemistry

for chemical processing and separation;

investigate possiuflities of waste

volume reduction, reduced energy or

reagent use, isotope se aration, etc. 
Program Area

1. ${ }^{238} \mathrm{PuO}_{2}$ Safety and Environmenta1 Support

2. TRU Waste Treatment and Disposal

3. $\mathrm{UO}_{2}$ and $\mathrm{ThO}_{2}$ Skull Melting

4. RAD Waste Degradation Studies
FY78 Operating Funds (\$K)/Source

Future

Principal objectives

Currently Funded Programs

Provide 1ndependent assessments of safety aspects of space and ter-

restrial nuclear power systems; to determine chemical responses of $238 \mathrm{PuO}_{2}$ fuels in contact with the environment.

In support of H Division (project 3) /Thru H Division

Continuing

In support of CNC Division (project 6) /Thru CNC Division

Co.t1nuing

Study the radiolytic, thermal, catalyzed pyrolytic, and chemical and 352/ONWM-DOE /SL

Continuing

Continuing

biological degradation gases pro-

duced by the interaction of radio-

active waste and the storage media. 
CHEMISTRY NUCLEAR-CHEMISTRY (CNC) DIVISION

Program Area

1. Radionuclide Migration Project

2. NTS Terminal Waste Storage

3. Waste Isolation Safety Assessment Program
PY78 Operating Funds

( $\mathrm{SK})$ / Source

Future

175/NVO-DOE

Continuing

Quantify the distribution of radionuclides around underground nucleat explosions; determine the potential for migration of radionuclides produced in nuclear tests including

time-distance relationships under varlous test conditions; perform laboratory leaching and sorption studies.

Evaluate the major geologic formatlons at the Nevada Test Site (NTS)

as to their suitability for deep

geologic storage; Investigate

Elsana argillite, Climax Stock

granite, and a variety of tuffs;

perform laboratory sorption studies

under equilibrium and non-equilibrium

cond it lons.

Radionuclide transport studies; a general study of the sorption properties of materials potentially useful

for deep geologic storage; study

sorption mechanisms using granite

and argillite; study chemical behavior In basic medta.
225/NVO-DOE

Expand 1ng

$127 / O N W I-D O E$

Expanding 
4. Natural Fission Reactors

5. Release Rates of Reactor Products from Stored Fuel Elements, Synthet1c Uraninite, and Natural Reactor Ore

6. $\mathrm{UO}_{2}$ and $\mathrm{ThO}_{2}$ Skull Melting

8. Heats of Pormation of Minerals
7. Dissolution of Rocks and Mineral
FY78 Operat1ng Funds

\section{Currently Funded Programs}

Measurements of the extent of fission product migration and the influence of geological enviroment

on retaining residues from a two

billion year old reactor.

Development of an apparatus to costrol oxidation conditions and measurements of reactor product

release rates at temperatures like those in geologic storage and with controlled oxidation conditfons.

Determination of reactor product retention in large crystals of $\mathrm{vO}_{2}$ or $\mathrm{ThO}_{2}$.

\section{Related Programs}

Determination of the rates of dissolution of rocks and alnerals, and the solubilitles of pure minerals in aqueous solutions under static and flowing conditions up to $300^{\circ} \mathrm{C}$.

Measure the heats of forwation of minerals using a molten salt calorimeter.
250/ONWI-DOE

Expanding

300/ONWI-DOE

Expanding

100/ONWM-DOE

Continuing 
9. Geothermal Circulation Loops and Element Migration Studies

10. Permeability and Trace-Element Studies

i 11. Chemistry of Oxo-Complexes of the Light Actinldes. Theory and Expertment

\section{Determine tock-water interactions} in a controlled temperature

gradient; study element sources, migration mechanisms and sinks in geologic systems.

Measure the matrix permeability on samples from a variety of sites; observe connecled porosity using radiotracers, autoradiograms, and scanning electron inicroscopy; determine trace elements by neutron actimine trace $\in$ lement
vat ton analysis.

Extend the knowledge of the chemlcal and structural properties of the early pentavalent oxo-complexes and other related compounds; perform horizontal comparisons of chemical bonding along a series of actinide compounds; gain understanding of behavtor of these elements under the "oxo-f avoring" condit tons frequently excountered in waste handling schely and in the biosphere.

\section{Potential Program}

Measurement of ${ }^{135} \mathrm{Cs}$ retention in uranium ores and characterization of fisston product mobilization processes for model development. 
GEOSCIENCES (G) DIVISION

Program Area

1. NTS Terminal Waste Storage Program

2. Hot Dry Rock Geothermal Energy Demonstration Project

3. LASL Alternate Energy PrograuGeothermal Space Heating
FY78 Operating Funds

$(\$ K) /$ Source

Future

Currently Funded Program

Evaluate a variety of tuff formations at the Nevada Test Site

(NTS) as to their suitability for

deep geologic storage; study re-

gional geology, 1ithology, and

petrology; perform rock physics

studies on tuffs; perform field

mapping and 1ithologic logging of

a test well.

\section{Related Programs}

Develop technology for establishing closed loop f.. ow systems in deep, hot rock; scudy heat trans-

fer in fractured 1gneous rock,

remote fracture mapping, thermal

stress cracking, effects of fluids

on mechanical response, permeability,

flow paths, high-temperature down-

hole instrumentation, and rock-water

interactions.

175/NVO-DOE

Expanding

Study the feasibility of a geothermal

facility for space heating in LASL;

geological and geophysical explors

tion to determine the profile of

basement rocks and possible ground

water flow patterns. 


\section{GEOSCIENCES (G) DIVISION}

Program Area

4. In-Situ Coal Gasification
Principal objectives

\section{Related Programs}

Develop technology for gas production from coal seams by in-situ ignition of the coal; study fluid flow, thermal stress cracking, enhancement of permeability by chemical leaching, and connective heat transport In multiphase systems.

\section{Potential Programs}

5. Silicate and Titanate Analogues of Natural Minerals as Waste Forms

Investigation of the feasibility of incorporating radioactive fission products into silicate and titanate analogues of natural minerals; study natural erystal chemistry using

natural crystal chemistry using

mineral synthesis electron micro-
probe, and $x-r e y$ diffraction methods.

6. Fission Product Migration in Large Thermal Gradients

Determine the direction of migration of fission products when placed in a large thermal gradient in a relatively small block of host rock.

Study three fallure modes that could result in increased fracture permeability: brittle tensile fracture, brittle compressive (shear) fracture, and tertiary creep fallure; effect of temperature, pressure, and pore pressure. 
GEOSCIENCES (G) DIVISION

Program Area

8. Low-Strain-Rate Behavior of Bulk and Jointed Maf $1 \mathrm{c}$ Rocks
Principal objectives

\section{Potentlal Programs}

Srudy the mechan 1 cal properttes of mafic igneous rocks on the Hanford Reservation; study the

hlgh temperature rheclogical pro-

perties of the rock matrix and 1 ts

constituent minerals; study the

shear and tensile strengths of

jointed basalts sealed by zeolite

minerals. 


\section{Princ1pal object1ves \\ Currently Funded Programs}

1. Filter Test Methods for A1r Cleaning

2. Evaluation of Transurantum Contaminated Waste Burlal Sites

3. TRU Waste Treatment Demonstration and Assay Instrumentation Development

4. Radioactive Waste Burlal Technology

5. Haste Management Requirements for Alternative Fuel Cycles
FY78 Operating Fund Sk/Source)

Future

Develop laser-based systems and test materials for 1n-place testing of HEPA filters.

Develop system to assess adequacy of shallow land disposal site

containment.

Develop and demonstrate controlled a 1 incineration as technique for reducing waste volume and enhancing chenlcal form for disposal; storage controls on corrosion and radiolysis; demonstration of electronlc waste package assay systems; modifications to incinerator for remote tons to inclnerator for remote
control operation; development of non-destructive waste assay systems for wastes from both DOE and commerc1al operations.

Develop site selection, site engineering, site monitoring technology for shallow land disposal; includes LASL sites.

Identify types, quantitles, forms, and any spectal problems associated with wastes from alternative fuel cycles.
190/ONWM-DOE

Decreasing

144/ONWM-DOE

Expanding

1826/ONWM-DOC

Continuing

510/ONWM-DOE

Expanding

$130 / 0$ WWM-DOE

Continuing 
6. Stabilization of Uranium Mill

Develep tcological information on the movement of materials from tallings piles and evaluate vegetative and mechanical stabilization techniques.

7. Transport of Waste Radionuclides Through Soil

Develop information on nuclide transport by soil type and as influenced by microflora on solls at commercial waste burlal fac1lities.

Describe movement and effect of radionuclides in natural systems.

Ecological Behavior of Waste Materials at Los Alanios and Trinity Site.

9. Limits/Standards for Radionuclides in Environmental Media

Establish enviromental health limits for radionuclides in surface solls and for transuranic contaminants in materials going into shallow land disposal.

\section{Potential Programs}

10. Incinerator off-Gas Treatment Program*

Develop and demonstrate gaseous treatment systems for incinerators.

11. Exhumed Waste Processing Studies*

Develop volume reduction processes for waste exhumed from shallow earth burial sites.

100/BER-DOE

Future (\$K)/Source

$240 / \mathrm{NRC}$

Continuing

263/BER-DOE

Continuing

* A proposal exists. 
1. NTS Terminal Waste Storage Program

2. Detector vevelopment

3. Cohabltation of Weapons Testing and Waste Management Activities at the NTS

4. Site Selection for Nuclear Weapons Tests

5. Ground Motion Studies

6. Large-Scale Technical Ficld Programs

7. Porous Flow and Yydrofracture Yode is

\section{Currently Funded Programs}

Measurement and analysis of ground motions from nuclear weapons tests;

effects on posstble waste repository

effects on possible waste repository

Develop detectors for determining the amount of radioactivity present

in waste (in support of H-Division

projects 3 and 4 ).

Studies of joint use of the NTS for weapons testing and waste management activities.

\section{Related Programs}

Geologic and geophysical characterization of sites for nuclear weapons zation of sites for nuclear weapons
tests; drilling of emplacement shafts.

Estimate ground motion from nuclear explosions; effects of seismic disturbances.

Conduct large-scale fieid programs both for underground nuclear tests and for oil shale studies; field in-situ experiments to gather technical data; acquire and transmit data in extreme environmental circumstances.

Develop models with two-phase flow for weapons tests containment studies. 
Prugram Area

8. Monftoring of Nuclear Weapons Tests

9. Field Measurements for In-Situ Waste Management Experiments

10. Porous Flow, Hydrofracture, and Ground Motion Modeling

11. Advanced Detector and Monitoring Techniques

12. Geologic and Geophysical Characterization of a Site; Technical Field Programs
Principal objectives

\section{Related Prograns}

Obtain extensive data from nuclear weapons tests; design, fabricate, and field sophisticated equipment for data acquisition and analysis.

\section{Potential Programs}

Gather data needed for siting a waste repository; heater, radionuclide migration, rock mechanics, and porous flow measurements.

Modeling of ground water flow and ground motion for siting a nuclear waste repository; hydrofracture analysis and analysis to determine relevancy of hydrofracturing phenomena to storage of waste in water bearing rocks.

Development of field techniques for monitoring nuclear waste in an experimental facility and or in a permanent nuclear waste repository.

Locate sites and field large-scale technical experiments related to nuclear waste storage activitles. 
ENERGY (Q) DIVISION

Pragram Area

1. Safeguards Measurement Technology, International Safeguards of Training

2. Nuclear Material Detection and Survelllance

3. Safeguards Matei ial Measurement and Accounting - DYMAC

4. Safeguards Systems Analysis, Conceptual Design and Evaluation of Fuel Cycle Facilities
Principal Objectives

Related Programs

Develop and transfer technology for the measurement of nuclear materials, with emphasis on nondestructive assay methods.

Develop methods and instrumentation for monitoring personnel and vehicles and other potential diversion mechanisms and for survelllance and 1 tem accounting of materials in storage.

Develop, implement and test

plant-wide, automated measurement and accounting systems; test and evaluate the Dymac Materials Contro1 (DYMAC) System at the LASL TA-55 plutonfum facility.

Model and simulate processes and measurement systems for assessmen: of safeguards for existing facilities and design of safeguards systems for future fuel cycle facilities: develop decision analfacilsi evate international safeguards strategles. 
Program Area

5. Ceramic Heat Pipe

6. Nondestructive Assay Technology for Urantum Resource Evaluation

7. Waste Management by Measurement *

8. Active/Pazsive Neutron Assay of Fission Product TRU Haste

* A proposal ex1sts.

\section{Principal objectives}

Related Programs

Develop high temperature heat removal devices for recovery of injustrial waste heat; invest 1gate feasibility of using heat pipes to remove heat from fuel cycle materials.

Apply gama-ray and neutron computer codes to problems encountered in uranium exploration by borehole in uranium exploration by borehole applications.

\section{Potential Programs}

Identify points in the fuel cycle where nondestructive assay (NDA) instrumentation can be used for waste management; develop and test NDA measurement systems for these problems including instrumentation for the Federal Haste Repository.

Construct and test a neutron interrogation and detection system capable of measuring f1asion-product contaminated $\left(\sim 103_{R} / h r\right)$ TRU waste at the $10 \mathrm{nC1} / \mathrm{g}$ level in 55-gal drums - a reprocessing plant problem. 
ENERGY (Q) DIVISION

Program Area

9. Leached Huils Monitor

10. Transfer of Safeguards Material Management Technology for Waste Management
Principal objectives

Potential Programs

Develop and test a nondestructive assay system for quantitative measurement of the fissile content of leached hulls from reprocessing plants.

Transfer and adapt technologles for the automated materials measurement the automated

and accounting safeguards systems

for the purposes of efflcient waste management at the source factilties. 
SYSTEMS ANALYSIS AND ASSESSMENT (S) DTVISION

Program Aree

1. Statistical Support for Nuclear Accountability Program

2. Sensitivity Analysis of Tranaient Resctor Anglysis Code (TRAC)

Nuclear Fuel Cycle Option Model
Principal Objectives

Related Programs

Examine uranium and piutonium inventory data and shipper-receiver data for trends or significance

in differences, including ana-

lysis of possible cumuiative

effects of measurement error.

Determine the sensitivity of the calculated variables (outputs) of TRAC to the input variables.

\section{Potential Program}

Trace and calculate the fuel use efficiency, costs, net enerby,

economics, effluents, and relative proliferation zesistance of various nuclear fuel cycle options, considering different enrichment processes, resctor types, reprocessing and recycle options, etc.; use results to compare nuclear fission to other energy technologies and intercompare fission technologies, including implications for waste management. 
THEORETICAL（T) DIVISION

Program Area

1. Computer Modeling of the Transport of Radioactive Waste in Geological Med 1a

2. Distributions of Cracks in Rocks

3. Development of the Data Base Characterizing the Radionuclide Decay Chains for Waste Materials

4. Computer Modeling of Fluid Flow threugh Porous Media
Principal Objectives

Related Programs

To develop a modular compute code to use as a predictive

tool in assessing the migration

of radionuclides in geological

repositor 1es.

To develop probabilistic

analytical tools to describe the distribution of cracks 1n rocks.

To develop a data base for vatious physical properties of nuclei including decay probabili ties; such data is essentlal for describing the chemical and thermomechanical properties of waste materials.

\section{Potentidl Program}

To develop a computer code to describe the fluld flow through porous media. 
DIVISIONAL CAPABILITIES 


\title{
AP-DIVISION CAPABILITIES
}

The Applied Photochemistry Division has demonstrated a laser scheme for isotope separation. The Division consists of four major groups which are roughly divided as to function:

\author{
$\mathrm{AP}-1$ Process and Laser Engineering \\ AP-2 Laser Reserach and Development \\ AP-3 Laser Applied Spectroscopy \\ AP-4 Applied Photochemistry and Process Research
}

The principal elements of the AP-Division method for separating the isotopes of uranium are the use of $U_{6}$ in a carrier gas as the process medium, the use of infrared and ultraviolet lasers to achieve the isotope separation, and the use of supersonic cooling to achieve the proper spectral simplification. Striving to achieve the scientific and technical demonstration of the concepts embodied in the laser isotope separation plan has led to the development of divisional

expertise in: 1) laser spectroscopy; 2) on-line diagnostics with lasers;

3) optical system design and beam transport; 4) on-line computer control and diagnostics; 5) picosecond diagnostics; 6) gas dynamics and fluid mechanics; 7) mechanical design; 8) high-voltage engineering; and 9) various aspects of molecular beam systems, mass spectrometric diagnostics, supersonic flow diagnostics and component testing, and the preparation of nonlinear crystals.

The Division has pioneered in the application of supersonic nonequilibrium flow cooling as a tool for molecular spectral simplificaticn, in the use of diode lasers as monitors of molecular density in supersonic flows, and in the design of new laser systems and the beam steering optics to shape and direct laser beams over meters of path length to specific target volumes in both static and dynamic gas systems.

The Division has expertise in laser induced fluorescence, in the use of two and sometimes three lasers as diagnostic tools in unraveling the intricacies of molecular interactions and reactions, in the design and control of supersonic flow systems, in the design of complete laser systems, and in electric and electronic engineering.

The CMB Division has extensive facilities and expertise in handling various radioactive materials in small to large quantities. They have extensive capabilities for studying radioactive wastes, waste processing, storage, and reduction in volume. 
Group CMB-1 has equipment and expertise for handling ${ }^{238} \mathrm{Pu}$ and for studying its effects under various environmental conditions both terrestrial and aquatic. Group CMB-1 also has the expertise and facilities to study corrosion of containers, radiolytic and chemical attack of various waste matrices and containers, and of potential waste packaging materials in laboratory and in waste disposal environments. Investigations can be carried out at ambient or high pressures and temperatures. They are equipped to provide analytical chemistry support for a wide range of tests and studies in waste management.

Group CMB-8 has expertise in studying geologic disposal and the physical chemistry relative to geologic formations.

Group CMB-11 has capabilities and facilities for categorizing, sorting, and processing wastes, for reclamation of processing materials to prevent their becoming waste, for packaging studies, and for placing waste in simulated storage and monitoring it. They also have the facilities for handing large quantities of radioactive materials.

Group CMB-14 has the expertise and facilities for handling and investigating high $\alpha, \beta, \gamma$, and neutron radioactive materials in well-equipped hot cells. They provide support to the program involving placing high-level wastes in a $\mathrm{VO}_{2} \mathrm{matrix}$ in deep geologic disposal. The facility is used to near capacity but could support a small effort in studying irradiated fuel wastes.

CNC-DIVISION CAPABILITIES

CNC Division is a small but very active division of LASL with strong interests in basic understanding and applications of nuclear chemistry, radiochemistry, geochemistry, actinide chemistry, and the structure, spectroscopy and reaction kinetics of inorganic substances.

Group CNC-2 has extensive knowledge of and experience in studying the kinetics of the oxidation reduction reactions of actinide elements. This capability and knowledge is fundamental in order to be able to study and understand the near-neutral solutions that may be present in geochemical environments. This group also has the capability of measuring the heats of formation of minerals and from these calculating the free energies of formation. These data allow the prediction of multicomponent equilibrium in geothermal systems. The rates of dissolution of rock and minerals and the solubilities of pure minerals can also be determined. 
Group CNC- 4 has significant expertise in the basic actinide chemistry jermane to the design of improved waste treatment systems. The group has capabilities for the study and synthesis of improved, highly specific actinide complexing agents, for the study of the differential chemistry of actinides in unusual chemical environments and oxidation states, and for the application of state-ot-the-art physical-chemical characterization techniques to process problems and design. These capabilities include equipment For multinuclear NMR, single-crystal X-ray diffraction, UV-visible spectroscopy, and IR-Ranian spectroscopy.

Group CNC-11 has traditionally provided radiochemical diagnostics for l.ASL-sponsored weapons tests. Results from radiochemical and isotopic assay of weapons debris samples are interpreted in terms of weapons performance parameters (yield, efficiency, neutron fluence). A close coupling of basic and applied research has historically been a source of innovative progress. The group has strong interests in nuclear processes and theory, particularly fission, and, more recently, nuclear and chemical phenomena associated with mesuns and protons at ti.e 800-MeV LAMPF accelerator. They have specialized in the chemistry of fission products and heavy elements. Other group interusts and capabilities related to waste management include: 1) fission-product behavior in high-temperature reactor fuel; 2) occuzr nnce of Pu-244 and other long-lived nuclides in nature; 3) the oklo natural fission reactor in the Gabon uranium deposit; 4) radionuclide distribution and transport in geologic media at weapons test sites and in fallout from weapons tests; 5) particulates and other pollutants in the atmosphere; 6) interactions of water with rccks in geothermal systems; 7) solubility of, and fission-product release from, $\mathrm{UO}_{2}$ in a chemical enviroment; 8) mass spectrometry and electromagnetic isotope separation; 9) experimental chemistry and geochemistry; and 10) mathematical analysis and modeling.

G-DIVISION CAPABILITIES

The Geosciences Division (G-Division) was established in early 1977 in urde: to place many of the geosciences activities at the Los Alamos Scientific liabo atory under a single management. This change reflects an appreciation of the growing importance of geosciences in a national environment of increasing shortages of energy and resources.

The largest single program in the Geosciences Division is the geothermal program, particularly the research in hot dry rock at the Fenton Hill site near i.ASL. The Hot Dry Rock Geothermal Program involves fracturing of rock, the study of fluid flow through the fractured rock, and heat conduction by rock. The expertise of the geothermal program in these topics is directly applicable to problems of nuclear waste management. 
G-2, the seismology and geophysics group, is principally concerned with research in various aspects of seismology and supporting branches of solid earth geophysics. They undertake studies varying from crustal structure and tectonics of an entire region to the detailed seismic response of a single small site. Mobile telemetry and recording equipment are used. A considerable effort has been focused on development and field use of portable seismic, gravimetric and geomagnetic instrumentation. Other activities include development of special purpose instrumentation such as tilt and strain meters and engineering seismology.

Group G-6, Geological Research, is principally concerned with energy and environmental problems. Field geological and geophysical data and laboratory analytical. and computational facilities are employed to understand, characterize, and evaluate various energy-related problems. Research techniques employed by Group G-6 include field and laboratory geology and petrology, electron microanalysis, electron microscopy, and $x$-ray diffraction, transport properties of rocks and minerals, rock behavior under static and dynamic loading, and numerical modeling of physical and chemical processes.

\section{H-DIVISION CAPABILITIES}

Historically H-Division has been responsible for waste management operations at LASL. Experience and capability in packaging, measurement, transport, treatment of liquid wastes, compaction of solid waste, burial, storage, disposal documentation and waste disposal site monitoring have evolved. In addition to these operational waste management responsibilities, $H$ Division is conducting nuclear waste management research. These technology development programs began in 1972. The nature of this work has been in the areas of waste treatment engineering, aerosol waste collection engineering, waste-environment interaction studies, waste assay instrumentation development, and assessment and monitoring of shallow land radioactive waste disposal sites.

Group $\mathrm{H}-1$ has expertise in radiation measurement instrumentation which has resulted in development and application of assay systems for waste packages and for monitoring nuclide migration in the environment.

Group H-5 has expertise in aernsol physics and engineering which has been applied to high efficiency particulate aerosol (HEPA) collection systems and to trapping gaseous species such as radioiodine. Recent emphasis has been on developing laser based aerosol penetration measurement systems to test HEPA filters in-place. 
Group $1 \mathrm{t}-7$ has expertise in waste treatment engineering. This group operates the liquid waste treatment plants and the solid waste disposal sites for the Laboratory. Research, development and demonstration work is ongoing on waste packaging and treatment. Current emphasis is on development of the controlled air incinerator (CAI) process for volume reduction of combustible waste. A full-scale incinerator has already burned several tons of non-radioactive but representative combustibles. Demonstrations using radioactive waste will begin in early CY79. The development work is carried out in the radioactive waste treatment development facility (TDF). The TDF is utilized for design and tcsting at production scale solid waste treatment systems. Process engineering capabilities include design and testing of all support and instrumentation systems for waste handling and assay, waste preparation, treatment (e.g., combustion), and handling of treatment residues.

Group H-8 has environmental and analytical chemistry capabilities. Measurement of radioactivity in soil and other environmental media down to natural background levels in thousands of samples per year is a routine capability via wet chemistry techniques.

rroup H-12 has ecological, hydrological and geological expertise which is being applied to problems of environmental behavior and migration of radionuclides. Emphasis has been on near surface disposal of transuranic waste materials and the radioecological implications o! these nuclides.

\section{J-DIVISION CAPABILITIES}

The primary J-Division mission is "to execute nuclear device tests and carry out experiments and calculations on device performance and effects." .J-Division is comprised of scientific, engineering, and logistics groups. The efforts of the scientific groups include the acquisition and investigation of data derived from and pertinent to nuclear tests, to determine the performance of nuclear devices, and to study the various phenomena related to nuclear explosions. The engineering groups are responsible for the desigh, consiruction, and maintenance of field-test facilities, mechanical design of the specialized equipment used in field testing, electrical engineering tasks including data acquisition, recording, telemetry, and the timing and firing of tests, and special electronic design. The Division has the interest, experience, and potential to utilize its unique capabilities on the problem of nuclear waste storage.

Group J-3, Operations-NTS, is permanently located in Nevada and is responsible for providing operational, administrative, and personnel support for the Laboratory's weapons testing program at the Nevada Test Site (NTS). 
Group J-6, Facflity Production, with offices at both the LASL and the NTS, is responsible for the design, construction, maintenance, and operation of LASL field test facilities a DOE test sites. The group is concerned with the solution of problems associated with mechanical, electrical, civil, and drilling engineering disciplines. The group acts as the Laboratory representative to the DOE and its engineering and construction contractors for the design, construction, operation and maintenance of these test facilities. The gruup has the primary responsibility for the design, fabrication, proof testing and quality control of the emplacement hardware; it has responsibility for emplacement and stemming operations; it is responsible for the planning and drilling of emplacement holes and for the planning and conduct of postshot drilling operations to obtain rad-chem samples.

Group J-8, Timing and Firing, Phenomenology Support, has three sections. The Timing and Firing Section compiles device information, signal, monitor, and electroexplosive firing requircments, and evaluates this information to provide the proper system for the tcst execution. The Data Acquisition and Reduction Section is responsible for the instrumentation for, and recording of, such measurements as temperature, pressure, acceleration, and ground motion. The Special Engineering Section provides design, development, and fabrication of specialized field test equipment.

Group J-9, Underground Nuclear Phenomenology, is concerned with the containment of underground nuclear tests. Effort is concentrated on rock dynamics, gas flow, stemming designs, shock wave propagation studies, and the analysis of data from prior underground tests. J-9 participates in emplacement-site selection and prepares the containment evaluation documentation.

Additional capabilities, which may be relevant to waste management programs, are performed in other J-Division groups. These include atmospheric science, protection and safety coordination, administrative services, design and fabrication of sophisticated mechanical hardware systems, acquisition and reduction of field data, modeling of stress wave propagation, fluid and gas flow, and hydrofracturing, and extensive instrumentation research and development.

\section{Q-DIVISION CAPABILITIES}

Q-Division activities in the area of fission applications are nur.lear safeguards, reactor safety, and heat transfer systems. The four Safeguacds Groups in Q-Division have as their sole function the development of technology for the measurement, control, and management of nuclear materials, including most categories of waste relevant to waste management. Briefly, the disciplines and activities characterizing each of the Safeguards Groups are: 


\section{Divisional Capabilities}

Q-1 Development of nondestructive assay (NDA) techniques; test and evaluation of quantitative measurement systems; NDA technology training; NDA standards development.

Q-2 Development of detection, surveillance and verification instrumentation; nondestructive verification of weapons components; search and recovery. operations.

Q-3 Design and test of plant-wide automated materials measurement and accounting systems that incorporate NDA instrumentati، - Dynamfc Materials Control (DYMAC).

Q-4 Systems Analysis: Computer modeling and simulation of fuel cycle pricesses and measurement systems; conceptual designs of safeguards systems for existing and future nuclear factlities and alternative fuel cyclus; assessments of safeguards effectiveness of nuclear material measurement and accounting systems.

A range of techniques has been developed under the LASL Safeguards Prograin to measure quantitatively recycled scrap and to provide data for low-level transuranic waste with suffici_.: accuracy for sorting at the $10 \mathrm{nci} / \mathrm{g}$ fiducihl for permanent burial. Cooperative projects to test and evaluate NDA instrumlints have been conducted with almost all of the major nuclear operations in this country, which include facilities for LWR fuel cycle and the production cycle For national security. Current efforts focus on the development of plafit-wide automated materials measurement and accounting systems based on nondestructive assay instruments coupled to a computing system.

In other Q-Division groups, background capabilities relevant to waste management have been developed as a result of their participation in experimental and theoretical studies of the safety of reactor cores for LWR LMFBR, and HTGR reactors. The well-known LASL criticality safety itudies arf performed in Q-Division.

\section{S-DIVISION CAPABIIITIES}

The Systems Analysis and Assessment Division was formed in Afril, 1978, to provide a division-level focal point for interdisciplinary system/s analysis and assessment activities at LASL. The. Division is chartered to conduct both qualitative and quantitative analysis and assessment. Its capabllities are being broadened to include technology assessment and environmential assessment functions. The Division is an interdisciplinary team of profeşionals with 
expertise in such fields as sociology, economics, data base management, statiscics, energy modeling, environmental analysis, geography, computer programming, engineering, physics, nuclear science, environmental planning, technical communication, and consumer information programs. Initially, the Division has two groups: S-1, Statistics; and S-2, Energy Systems and Economic Analysis.

S-1 Statistics Group activities include statistical consulting, statistical research and methodology development, statistical training, and maintaining a library of statistical software. The areas of current research and development of statistical methodology related to nuclear wasre disposal include: 1) statistical analysis of chemical data; 2) analysis of the effects of radiation on life processes; 3 ) curve fitting and modeling; 4) development of statistical methods for use in the safoguarding of nuclear materials; 5) analysis of uranium sample data from stream and aerial surveys; and 6) statistical reliability cechniques and risk-cost-benefit analyses for reactor safety.

S-2 Energy Systems and Economic Analysis Group activities provide an interdisciplinary group of physical and social scientists for the evaluation and assessment of the soctal, environmental, economic and legal aspects of energy related programs. Numerous examples can be provided to demonstrate that the problems of the energy crisis transcend technology and in many instances defy technological solutions alone. Such problems are addressed by the economists, sociologists, physicists, and engineers in the group.

S-Division capabilities include statistical methodology development, techniques of sensitivity analysis, systems modeling, computer generated graphics and mapping overlay system and data base management.

\section{T-DIVISION CAPABILITIES}

\footnotetext{
Groups of $T$ Division perform basic research in medium energy physics, particle physics, solid-state physics, charged particle beam physics, molecular physics, theoretical chemistry, theoretical biology, and applied mathematics. Theoretical problems that fall within the areas of expertise of the various groups would be clearly of interest. More applied physics groups of the Division conduct research in particle transport modeling, nuclear data, fluid dynamics, and equations of state and opacity. These latter groups have skills that can be applied to the problem of modeling a repository to include source characterization, and radionuclide migration.
} 
DIVISIONAL FACILITIES 


\section{AP-DIVISION FACILITIES}

Tunable laser sources

- Nd:YAG laser pumped optical parametric oscillator

- HF laser pumped optical parametric oscillator

Semiconductor diode lasers

10m White cell for IR and UV absorption measurements

Optics control and measurement laboratory

Eclipse S/230 computer for control and data reduction

NOVA $3 / 12$ computers and data acquisition systems

Streak camera

Supersonic flow systems

Gas dynamic testing laboratory

Laser applied spectroscopy laboratory

\section{CMB-DIVISION FACILITIES}

Hot cells for handling high-level gamma radiation Shielded irradiated fuel storage

Environmental chambers

Soil columns

High-pressure chambers

Automated instrumentation

Excitation sources

High-temperature, high-vacuum furnaces

Induction Heating facilities for:

Annealing

Casting

Decarburizing

Melting

Outgassing

Preparation of ultra-high-purity alloys

Sintering

Soldering-brazing

Spherodizing 
Equipment to perform the following procedures:

Atomic absorption spectrophotometry

Emission spectrophotometry

Auger spectrophotometry

Mass spectrometric determinations

High-temperature mass spectrometry

Photoelectron spectroscopy

High-resolution emission spectroscopy

$\mathrm{X}$-ray absorption

$X$-ray diffraction

$X$-ray fluorescence

Ion microprobe examination

Elfctron microprobe examination

Neutron activation analysis

Neutron diffraction

General wet chemica? analyses

Radiochemical analyses

Spectrophotometry

Electrometry

Gas chromatography

Thermogravimetry

Thermal analysis

Differential thermal analysis

High-vacuum and inert gas fusions

Studies in:

Environmental chambers

Soil columns

High-pressure chambers

Chemical vapor deposition

Physical vapor deposition

Tritium handling

Plasma arc spraying

Flame spraying

Thick film technology

Scanning electron microscopy

Mechanical cesting

Solid surface-gas reactions

Low energy electron diffraction

Gamma irradiation

Proton irradiation

Laser pyrolysis

Metallography

Electron microscopy

Measurements of optical spectra to determine:

Wavelength

Spectra lines

Opacity

Radiation damage 
Fabrication of :

Plutonium metal and oxide

Uranium metal and oxide

Reactor fuels

Preparation of ultra-high-purity electrorefined plutonium metal.

Determination of high-temperature thermophysical, mechanical, and chemical properties of ceramics.

\section{CNC DIVISION FACILITIES}

\section{Chemical Laboratory Space}

General-purpose laboratories

Low-1eve1 chemistry areas

High-level chemistry areas
- one-man modules with hood (30)

- fume-hoods in larger rooms (30)

- rooms withoul hoods (7)

- hot cells ( $12 \times 100 \mathrm{Cl}, 1 \times 1000$ Ci) for gamma-active samples

- dry-box areas for alpha-active samples, 12 boxes, 3 hoods

- "clean-room" for particulates

- clean laboratory for ${ }^{244} \mathrm{Pu}$ studies

- "clean hoods and clean benches"

- "clean-room" for sample dissolution

- "clean-room" for mass spectrometer sample preparation

\section{Instrumental Areas}

Counting rooms
- automatic beta counters

- alpha counters

- NaI and Ge gamma-ray spectrometers

- beta and alpha spectrometers

- computer control and data collection

- computer data reduction 


\section{Instrumental Areas (continued)}

Moiten salt calorimeter

High-pressure, high-temperature solubility systems

High-pressure flow systems

Scanning-electron-microscope with non-dispersive X-ray analyzer

Emission spectrophotometer in hot cell for high-level samples

Atomic absorption spectrometer in fume hood

$X$-ray fluorescence spectrometer; automatic read-out and data analysis

Multinuclear NMR capability with FT and SC magnet

State of the area IR-Raman spectroscopy facilities

UV-Visible spectroscopy equipment

Single-crystal X-ray diffraction equipment; automated single-crystal diffractometer

Equipment for preparation of air-sensitive compounds

Fluorination equipment

Equipment for trapping netastable species

Mass spectrometers

- two surface-ionization, pulse-counting instruments in "clean-room"

- three surface-ionization, faraday-cup

- one "precision-ratio" gas-source

- one gas-source two-stage for "heavy methanes"

- two magnetic deflection isotope separators

\section{Computers}

LASL Central Computing Facility - access through local computer-baseciterminal

- access through several local keyboard terminals

Local computing capability

- PDP-11 and PDP-9 equipped and available for Fortran language computing

- PDP-11 and PDP-9 incorporated into counting room data processing system

- several mini- and micro-processors used for data collection and reduction 
Divisional Facilities

G-DIVISION FACILITIES

Controlled strain rate l-GPa/gas triaxlal apparatus for strength and deformation measurements.

$1.4 \mathrm{GPa}$ gas hydrostatic pressure apparatus for measurement of acoustic and electrical properties at high pressure.

3 GPa solid-media controlled strain rate device (Griggs apparatus).

Modified, wicroprocessor controlled Griggs apparatus for controlled stress and controlled strain tests; acoustic emission apparatus based on laser technology.

Thermal stress cracking equipment consisting of controlled oven and acoustic emission units.

Direct shear apparatus for measuring shear strength or friction between two surfaces.

40,000 1b. servo controlled testing machine for axial strength tests and low stress compression measurements at various temperatures.

Tinius Olsen testing machine for general materials testing.

Instron testing machine for fracture toughness and compressive strength measurements.

Triaxial pressure vessels for environmental tensile tests and moduli measurements. $500,000 \mathrm{lb}$. testing machine for use with the triaxial pressure vesseis.

H-DIVISION FACILITIES

Two active and twenty inactive solid (radioactive and hazardous chemical) waste storage and burial areas.

Solid waste treatment (compactor) facility (1500 sq. ft.).

Process engineering radioactive waste treatment development facility (TDF) ( $3500 \mathrm{sq}$. ft.) includes a $45 \mathrm{~kg} / \mathrm{hr}$ controlled air incinerator, X-ray package inspection equipment, waste assay instrumentation, waste shredder, and of $f$ gas treatment system; process equipment staging and warehouse area (2600 sq. ft.). 


\section{Divisional Facilities}

Temporary waste package storage shed (600 sq. ft.).

Liquid waste collection system for major LASL laboratory areas.

Liquid waste processing facilities (30,000 gal/mo); includes sludge collecting and handling equipment and pug mill for waste-cement mixing.

Wet chemistry laboratories for processing soll/rock samples and drill core material with low-level concentrations of radioactivity.

Low-level radioactivity measurement laboratory including alpha, gamma spectroscopy, and neutron systems.

Greenhouse laboratory for plant uptake and soil migration studies.

Aerosol collection and measurement laboratories including laser-based iustrumentation; instrumentation for aerosol and air cleaning studies is available; includes transmission and scanning electron microscopy, aerosol chambers and generators, and particle counting equipment.

Truck mounted auger; $100 \mathrm{ft}$. depth capability with selective core sampling.

Geophysical instruments: magnetometer; down-hole TV scanner; portaseismic; stratoineter; Am-Be neutron moisture probe; psychrometers.

Nuclear Waste Management assay systems include scintillation, $\mathrm{Ge}(\mathrm{LI}),{ }^{3} \mathrm{He}$, neutron, and proportional counting devices.

\section{J-DIVISION FACILITIES}

The very extensive facilities of J-Division are primarily related to the ability to conduct nuclear weapons tests in the field. Many of these facilities are in-house at LASL and represent state-of-the-art facilities. They include: extensive laboratories and associated equipment for the design and development of a wide variety of diagnostic techniques for measuring nuclear phenomena and for characterizing the in-situ envircnment surrounding a nuclear weapons test; design and fabrication of extensive mechanical systems; hardware and software for the handling and analysis of data; software for the analysis of phenomenology related to nuclear testing--from near the device to rock mechanics phenomena. 
In addition, J-Division's facilities are located with sub-contractors such as EG\&G's optical, electronics, and software support. The extensive facilities for the support of field activities located at the Nevada Test Site should also be included in J-Division's facilities. These facilities include hardware and the know-how for characterizing a site, drilling, logging and construction.

Because of their extent, J-Division's facilities are only very briefly described here. They might be best summed up by stating that J-Division could readily field extensive waste management experiments with state-of-the-art facilities.

\section{Q-DIVISION FACII.ITIES}

Neutron and gamma ray spectroscopy laboratories for the development of NDA instrunents for measurement of fissionable materials.

NDA standards laboratory including physical standards for fuel cycle materials. Van de Graaff accelerator and two Cockroft-Walton accelerators.

Custom electronics laboratory.

Shielded cells and remote handling for radioactive materials including ${ }^{252}$ Cf sources.

Critical assemblies including fast burst devices.

Heat pipe development laboratory. 


\title{
S-DIVISION FACILITIES
}

The major facility avallable to S Division is access to the LASL Central Computer Facility which consists of four CDC-7600 computers and a CRAY 1 class 6 computer. Extensive mass storage and other peripherals are also avallable. The Division also has special capabilities in computer graphic display systems and in computer mapping systems.

\author{
T-DIVISION FACILITIES
}

The major facility avallable to T Division is access to the LASL Central Computer Facility which consists of four CDC-7600 computers and a CRAY-1 class 6 computer. Extensive mass storage, graphics, and other peripherals are also available. 


\section{LASL TECHNICAL ORGANTZATION}

This report summarizes the current, related, and potential waste management programs for those Laboratory divisions presently involved in such activities. These divisions do not constitute the only technical divisions in the Laboratory that could contribite to waste management activities. The organization cha't given on the following page summarizes the IASL $t$.crnical organization. 


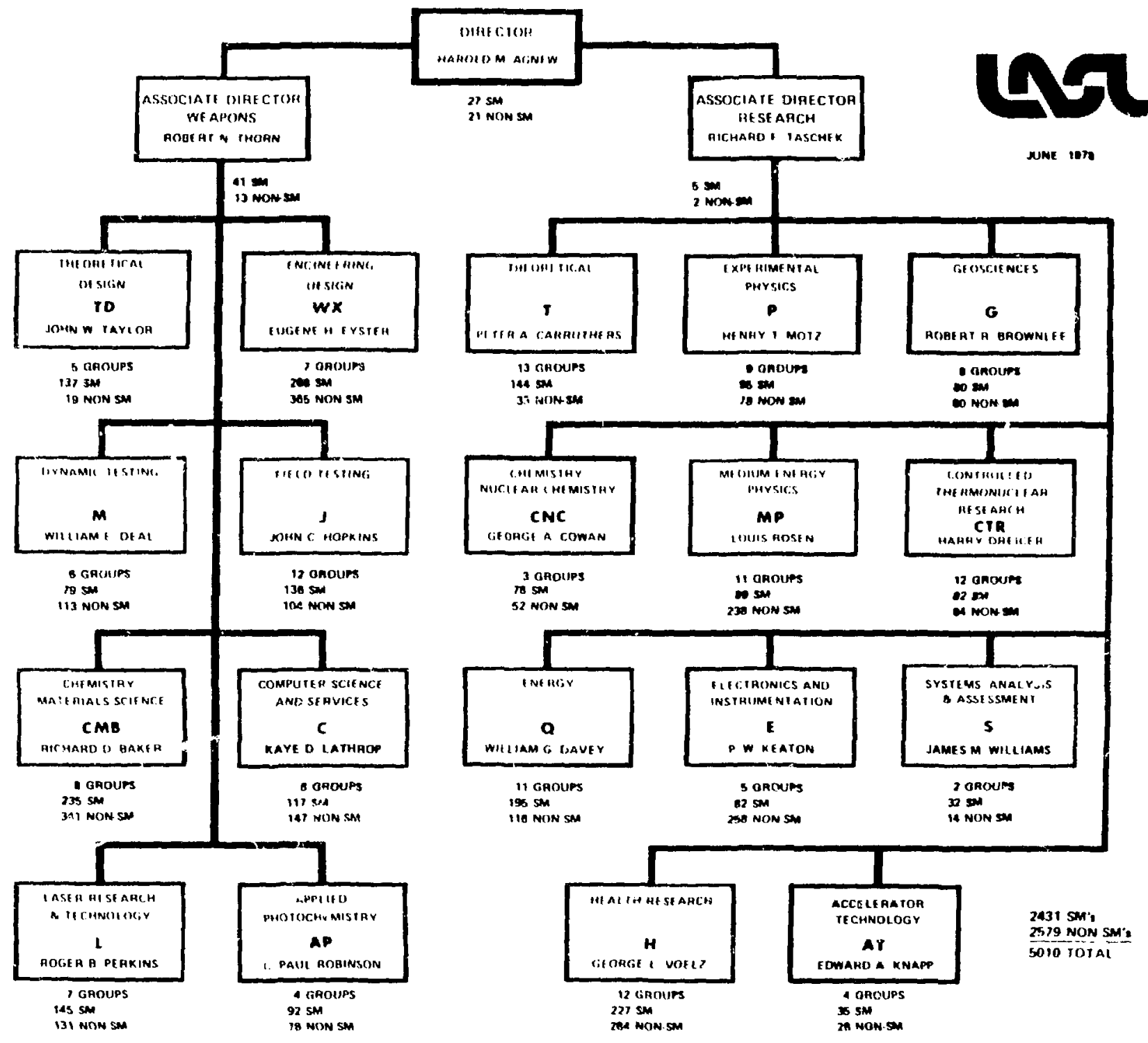

